\title{
Reproductive ecology of Panicum turgidum Forssk.
}

\author{
K. H. Batanouny, K. M. Zayed, H. M. Emad and H. F. Kabiel \\ Botany Department, Faculty of Science, Cairo University, Cairo, Egypt
}

K. H. Batanouny, K. M. Zayed, H. M. Emad and H. F. Kabiel, 2006. Reproductive Ecology of Panicum turgidum Forssk. Taeckholmia 26: 63-88.

\begin{abstract}
Panicum turgidum Forssk. is a drought-resistant $\mathrm{C}_{4}$ plant which exhibits high growth rates in late spring and summer months. Seed germination under different constant and alternating temperatures and the best time for propagation of this species were studied. The responses of the plant to different water regimes were also estimated. The present study revealed that the seed germination was successful under relatively high temperature. Propagation by transplants was favoured in months with moderate temperatures, so as not to cause excessive loss of water and drying of transplants. Cultivation of Panicum turgidum under different water treatments showed that its growth was greatly influenced by the amount of available water. The increase of growth was reflected mostly on the biomass, tillering capacity and the seed output.
\end{abstract}

Key words: Panicum turgidum, biomass, germination ecology, $\mathrm{C}_{4}$ plants.

\section{Introduction}

Panicum turgidum Forssk. is a widely distributed species that extends from the Atlantic Coast of the Sahara to Central India and from Cyprus and Tunisia to Somalia and region South of the Lake Chad (Williams and Farias, 1972). This species is one of the forage plants, which is always subjected to heavy grazing that researchers must be conducted to evaluate its transplantation in degraded rangelands and newly reclaimed lands. Due to its wide spread and deeply penetrating root system, Panicum turgidum is used as a sand binder (Williams and Farias, 1972). It is an effective sand binding xerophyte and may build up sand mound and hillocks (Batanouny, 1968, 1969; Zahran \& Willis, 1992). It is utilized in many other purposes e.g. as a wild human food (Nachgital, 1988; Maire \& Monad, 1950; Irvine, 1952; Zohary, 1962).

Received 30 September 2006, Revision accepted 11 December 2006 
Eighty percent of the world's population relies on traditional medicine to maintain its health (Weragoda, 1980). Panicum turgidum is also used in the nomadic medicine for removing white spots on the eye. Also, the powder from underground stems is used in healing wounds. This suggests that the species worth's further ethnopharmacological and ethnomedical study. In Egypt the species is a favoured livestock feed and is one of the most extensively grazed plants, and is usually overgrazed beyond its capacity to remain vigorous, especially in the summer when annuals disappear (Batanouny, 1981). Panicum turgidum is a drought-resistant $\mathrm{C}_{4}$ plant, which exhibits high growth rates in late spring and summer months (Batanouny, 2002). In addition, El-Keblawy (2004) indicated that Panicum turgidum is tolerant to grazing as buds on rhizomes under the soil surface are protected from grazers.

In Egypt, Panicum turgidum was recorded by Täckholm et al. (1941) in many parts of the country, (Fig. 1): in the Nile Delta, in the Nile Valley, in the Oases of the Western Desert (west of the Nile), in the Eastern Mediterranean Coastal Region and in the Isthmic Desert and in the Eastern Desert (east of the Nile) as well.

The present investigation aims at elucidating the effective method and the best time for propagation of this species. The responses of Panicum turgidum to different water regimes, biomass allocation, architecture and reproductive strategies were estimated.

\section{Materials and Methods}

\section{Seed Germination}

Panicum turgidum seeds were collected during summer of 1994 from plants growing in their natural habitats along Cairo-Alexandria desert road (120 km from Cairo). Seeds were kept at lab in air-tight containers at room temperature (average of $26^{\circ} \mathrm{C}$ ). The different stages of seed germination were described morphologically using a binocular with X20 magnification power. Germination experiments were undertaken under different temperature treatments during 1995 and 1996.

\subsection{Effect of temperature and light conditions}

Germination of intact and dehusked $P$. turgidum seeds was tested under different temperatures, in light and dark conditions. Nine $\mathrm{cm}$ Petri dishes were used each containing a filter paper (Wattman no.1) and moistened with 


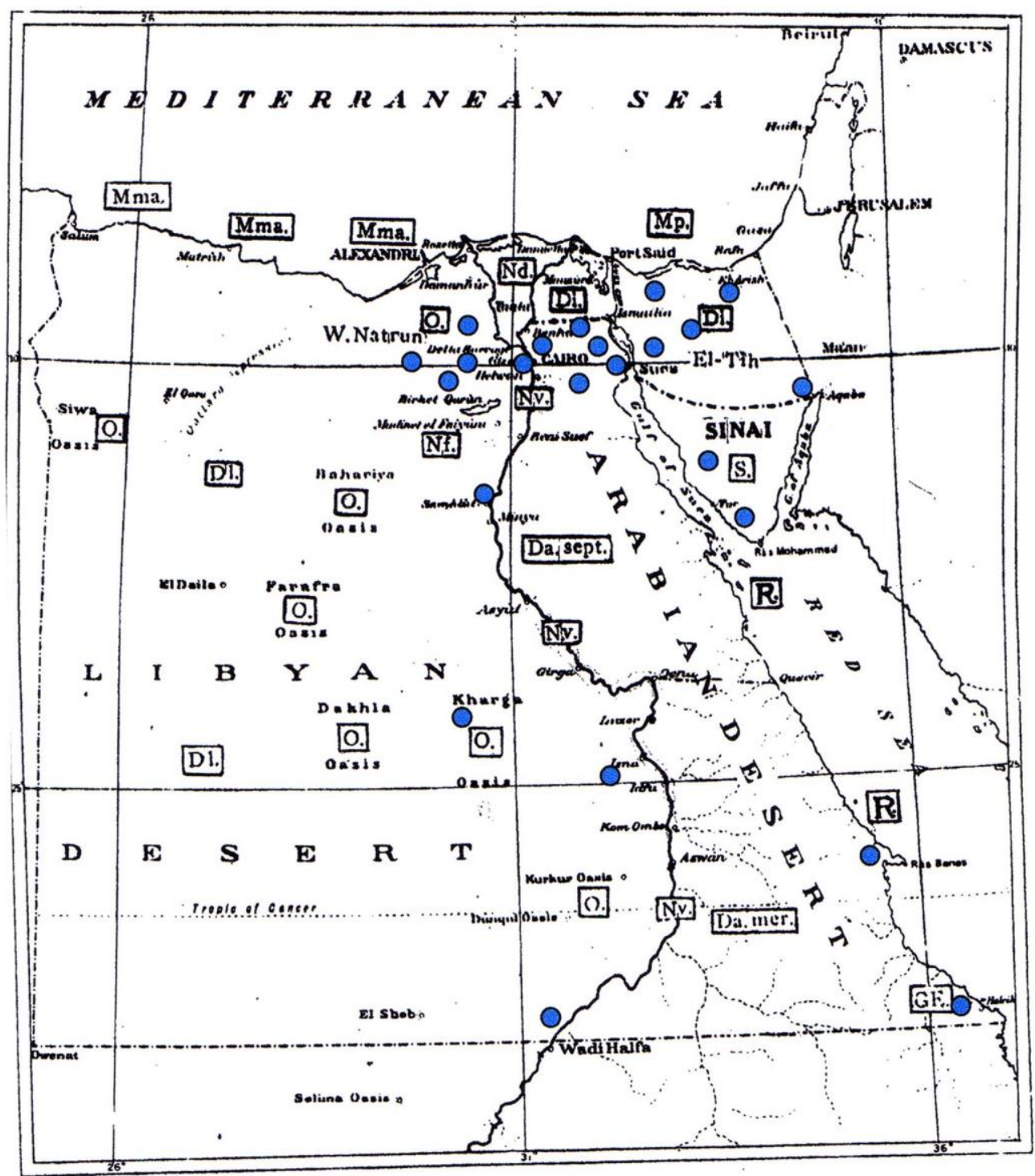

Fig. 1. Distribution of Panicum turgidum in Egypt; green circles referred to the locations of the species according to Täckholm et al. (1941). Nd.: The Nile Delta, Nv.: The Nile Valley, Mma.: The Western Mediterranean Coastal Region, Mp: Eastern Mediterranean Coastal Region Di.: The Ithmic Desert (El-Tih and the region north of Wadi Tumailat, S.: Sinai proper (south of El-Tih desert), Dl.:The Lybian desert, Da. Sept.: The Arabian desert from Wadi Tumailat to Qena-Qosseir road, Da. Mer.: The Eastern desert from QenaQosseir road southwards to the Sudan boundary, O.: Oasis of the Lybian desert, GE.: Gebel Elba and surrounding mountains. 
$5 \mathrm{ml}$ distilled water. At least two hundred seeds (four replicates of 50 seeds) were used for each treatment. Seed germination was tested under constant temperatures of $15,20,25,30,35$ and $40^{\circ} \mathrm{C}$, and alternate temperatures of $10-20^{\circ} \mathrm{C}$ and $20-30^{\circ} \mathrm{C}$ under 14 hours dark and 10 hours light conditions, respectively. Germinated seeds are those with a protruded radicle sheath or plumule sheath more than $0.5 \mathrm{~mm}$.

\subsection{Thermal and freezing treatments}

Intact seeds were subjected to thermal treatments at $40^{\circ} \mathrm{C}$ and $60^{\circ} \mathrm{C}$, for 4 hours daily in an oven for a period of 4 successive days, with and without moistening the seed surface with water just before introducing the seeds into the oven. At least two hundred seeds (four replicates of 50 seeds) were used for each treatment. Effect of freezing was also tested by putting the seeds in the refrigerator at $-6^{\circ} \mathrm{C}$ for 4 hours for 4 days. In another experiment, seeds were sown in pots and left for two months (June and July 1996) in the greenhouse under natural conditions with daily irrigation. The number of emerged seeds was recorded daily.

\section{Propagation}

\subsection{Propagation by transplants}

This experiment was carried out in a newly reclaimed farm at ElNoubariya (148 km north of Cairo) along Cairo-Alexandria desert road. The transplants were obtained from Panicum turgidum community growing naturally along Cairo-Alexandria desert road, $120 \mathrm{~km}$ north of Cairo. Clones were excavated by digging a furrow around each clone. The sand adjacent to the clone was carefully removed to a depth of $30 \mathrm{~cm}$ and lifted out of the soil. About half of the length of culms was clipped to reduce transpiration and to promote rooting and tillering. In the field, each clone was divided into units (transplants), each contains 2-3 culms and part of the rhizome with associated roots. Planting location were marked on the ridges $50 \mathrm{~cm}$ apart. At each location, $20-30 \mathrm{~cm}$ deep and $20 \mathrm{~cm}$ diameter soil plug was removed. The transplants were planted into the holes (one transplant within each hole). The rhizome and roots were completely buried in the soil. The transplants were irrigated weekly.

\subsection{Propagation by seeds}

Seeds of Panicum turgidum were sown during May 1995 in the green house at Cairo University. Wooden frames $(100 \times 100 \times 15 \mathrm{~cm})$ were used, placed on the ground at intervals of $50 \mathrm{~cm}$, and filled with a mixture of sandy and clay soil $3: 1$, respectively. The areas between the frames were filled with garden soil to prevent the break away of the frames. Seeds were 
sown in pairs (10 cm apart), using perforated wooden plate with a total of 200 seeds in each frame. The treatment was irrigated daily $(7.5 \mathrm{~mm}$ for each frame) for seven days, and then irrigated every other day for a month. Three hundred $\mathrm{mm}$ water was applied during cultivation period which extended for 4 months. Biomass, number of culms/plant, length of culms and water content were estimated.

\section{Responses of Panicum turgidum to different water treatments}

Three water treatments were used. Each treatment was represented by five replicates in wooden boxes $(50 \times 50 \times 50 \mathrm{~cm})$, filled with sandy soil that collected from the field and sieved through $2 \mathrm{~mm}$ sieve. Seeds were sown $10 \mathrm{~cm}$ apart in rows; 75 seeds were sown in each box. Irrigation was carried out daily during the germination period. After establishment of the seedlings, three water treatments $(570 \mathrm{~mm}, 650 \mathrm{~mm}$ and $790 \mathrm{~mm}$ for treatments I, II and III, respectively) were applied corresponding to a mean annual rainfall in the $1^{\text {st }}$ year (1996-1997). The corresponding values for the three treatments in the $2^{\text {nd }}$ year $(1997-1998)$ were $220 \mathrm{~mm}, 330 \mathrm{~mm}$ and 640 $\mathrm{mm}$. Culms of Panicum turgidum were harvested eight times, $1^{\text {st }}$ cutting $(28 / 11 / 1996), 2^{\text {nd }}$ cutting $(1 / 5 / 1997), 3^{\text {rd }}$ cutting $(1 / 7 / 1997), 4^{\text {th }}$ cutting $(1 / 8 / 1997), 5^{\text {th }}$ cutting $(1 / 9 / 1997), 6^{\text {th }}$ cutting $(1 / 10 / 1997), 7^{\text {th }}$ cutting $(1 / 4 / 1998)$ and $8^{\text {th }}$ cutting (1/8/1998). At each cutting, the seed production (number of seeds $/ \mathrm{m}^{2}$ ), shoot biomass and growth criteria were studied.

\section{Results}

\section{Seed germination}

Observations obtained from germination experiment of Panicum turgidum seeds revealed that seed coat constitutes a mechanical obstacle for the protrusion of the radicle. The plumule sheath protruded firstly followed by the radicle sheath. Whereas in the absence of seed covering (dehusked seeds), germination proceeded normally i.e. the radicle sheath grew first followed by the plumule sheath.

\subsection{Effect of temperature and light conditions \\ a. Intact seeds}

Figure (2) revealed that under constant temperature, the intact Panicum turgidum seeds did not germinate at a temperature of $15^{\circ} \mathrm{C}$. The percentage of germination increased by the rise of temperature until a maximum germination of $37 \%$ was attained at $35^{\circ} \mathrm{C}$. Temperature ranging from 20 $30^{\circ} \mathrm{C}$ showed higher values of germination percentage under dark conditions 


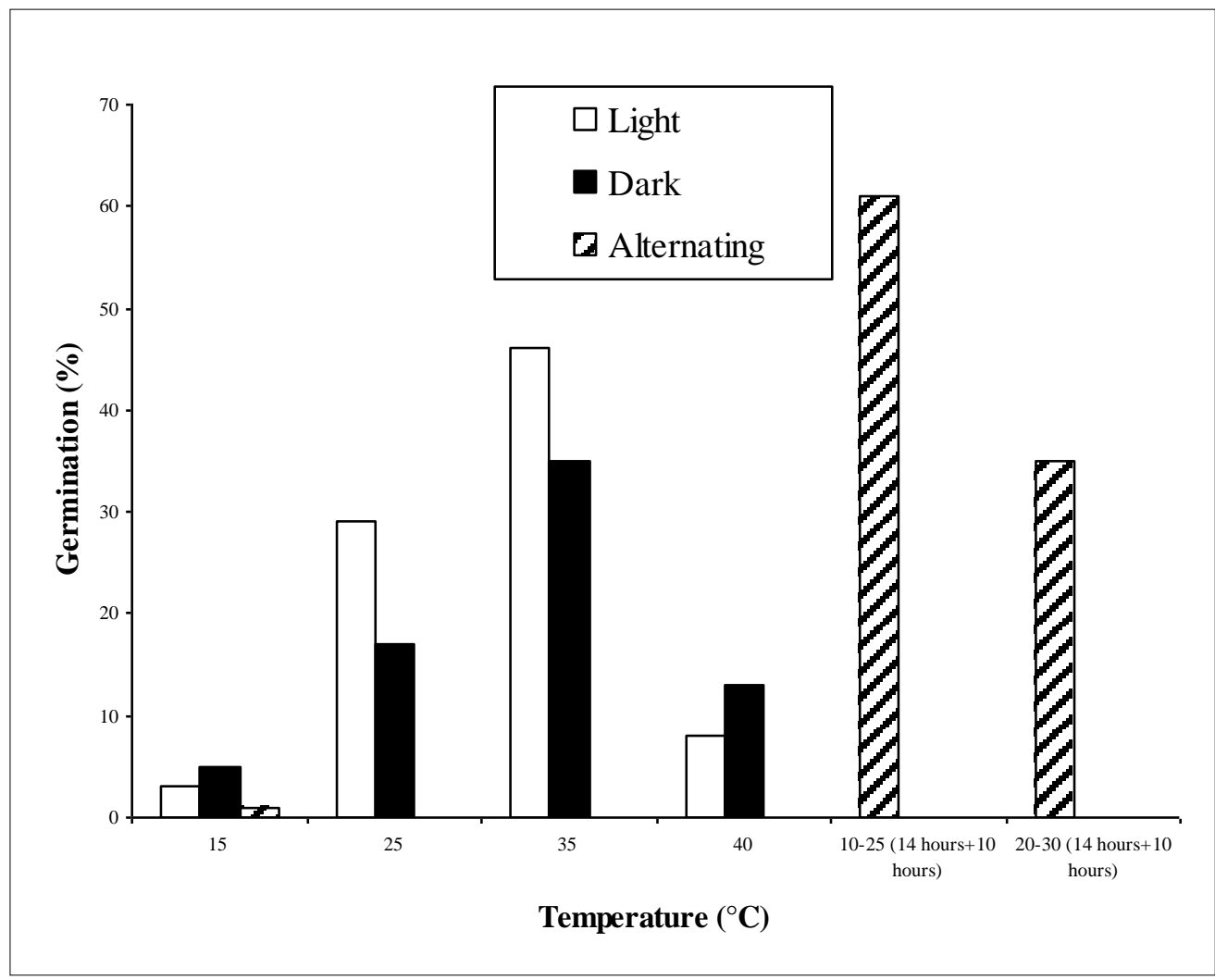

Fig. 2. Germination of intact Panicum turgidum seeds under different constant and alternating temperatures in light and dark conditions.

(31.7\%) than those under light $(21.7 \%)$. Also, alternation of temperature improved the germination percentage reaching a value of $51 \%$ at alternating temperature ranging between $10-20^{\circ} \mathrm{C}(14 \mathrm{~h}+10 \mathrm{~h})$. This value increased reaching a maximum value of $84 \%$ under alternating temperature $\left(20-30^{\circ} \mathrm{C}\right)$.

\section{b. Dehusked seeds}

On the contrary, germination of the dehusked seeds (Fig. 3) was favoured by light. Moreover, germination percentage started earlier. Maximum germination percentages amounting to $46 \%$ and $43 \%$ were recorded under constant temperature of $35^{\circ} \mathrm{C}$ under light and dark conditions; respectively. By time, the mortality of the resulted seedlings increased. This may indicate the importance of the seed covering for a 


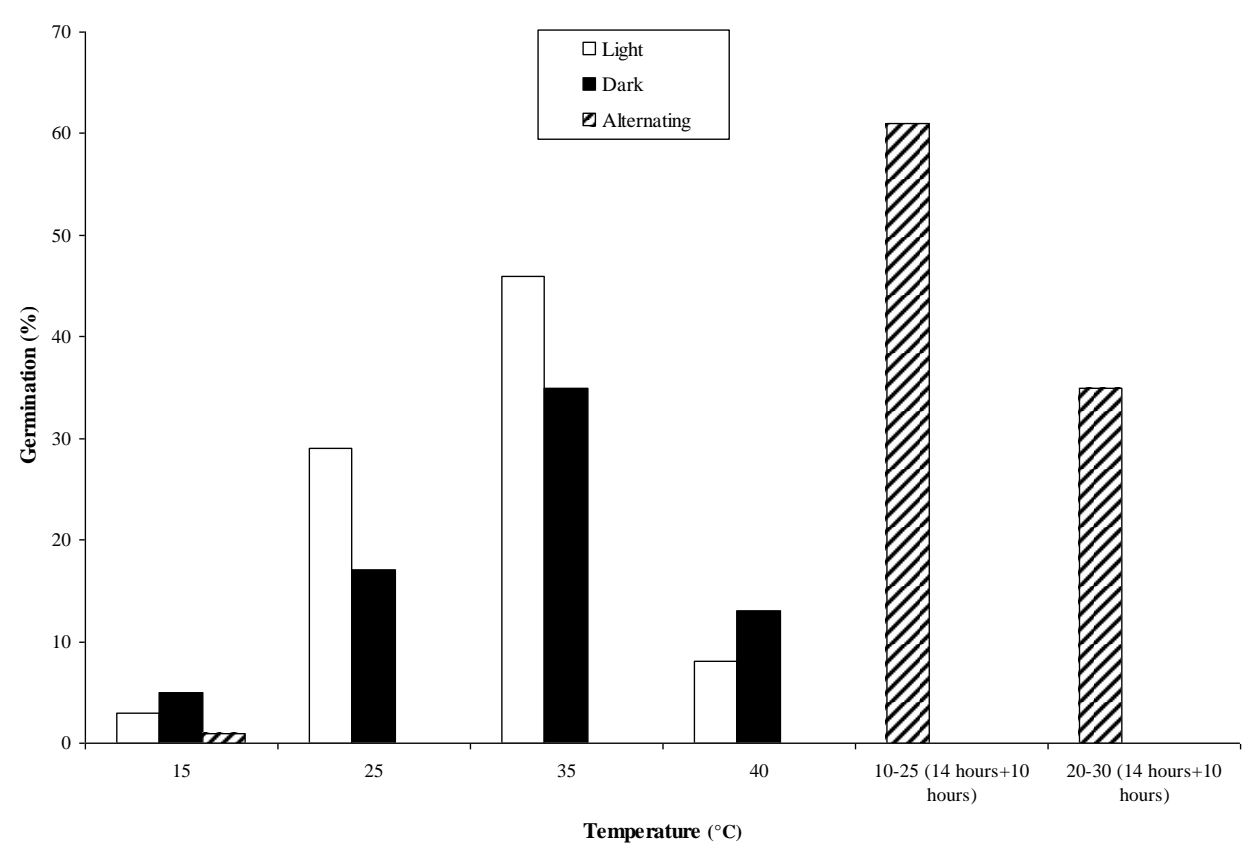

Fig. 3. Germination of dehusked Panicum turgidum seeds under different constant and alternating temperatures in light and dark conditions.

suitable seed germination process. Whereas germination of $63 \%$ was recorded in case of seeds subjected to alternating temperatures of $10-25^{\circ} \mathrm{C}$ $(14 \mathrm{~h}+10 \mathrm{~h})$, this value decreased to $51 \%$ when the germination was tested under alternating temperatures of $20-30^{\circ} \mathrm{C}$.

\subsection{Effect of thermal and freezing treatments on intact seeds}

Table (1) indicated that the highest germination percentage (22\%) was obtained by thermal treatment of dry seeds at $40^{\circ} \mathrm{C}$. shoot -dry weight attained a maximum of $70 \mathrm{mg}$ in case of seedlings resulting from thermally treated dry seeds at $60^{\circ} \mathrm{C}$, whereas a minimum of $23 \mathrm{mg}$ was recorded in dry seed germination at $40^{\circ} \mathrm{C}$. Under freezing conditions, germination percentage decreased from $14 \%$ in case of non-treated seeds (control) to a value of $5 \%$ at $-6^{\circ} \mathrm{C}$. However, dry weight of the root increased from a mean 
of $92 \mathrm{mg}$ in the control to a high value with a mean of $287.5 \mathrm{mg}$ in the root resulted from pre-freeze seeds.

\section{Propagation of Panicum turgidum}

\section{a. Propagation using transplants}

Data presented in Table (2) evince that:

1. Proper time for propagation of Panicum turgidum using transplants is that of April and October with sprouting percentage amounting to $55.2 \%$ in April and $50.5 \%$ in October, in these two months air temperature is more or less mild with a mean of $21.2^{\circ} \mathrm{C}$ in April and $27.8^{\circ} \mathrm{C}$ in October.

2. Sprouting greatly reduced to half of its values during the hot months of July and August with mean air temperature of $28^{\circ} \mathrm{C}, 28.3^{\circ} \mathrm{C}$, the estimated values of sprouting was $27.7 \%$ and $25.8 \%$ in July and August; respectively.

3. Sprouting decreased to value of $18.8 \%$ in the late autumn with mean air temperature $\left(18.3^{\circ} \mathrm{C}\right)$. By the advent of winter cold months the sprouting was completely ceased $(0.0 \%)$ where air temperature has a mean of $\left(14.7^{\circ} \mathrm{C}\right)$.

4. The present study evidences that the proper time for propagation of Panicum turgidum using transplants is that of April and October where air temperature is mild (ranges from 21.2 to $27.8^{\circ} \mathrm{C}$ ).

\section{b. Propagation of Panicum turgidum by seeds}

Fully matured seeds were sown in pairs, $10 \mathrm{~cm}$ apart within wooden frames. Five days after sowing, seedling emergence with a value of $10 \%$ was recorded. Seedling emergence increased gradually by time till it attained its maximum value of $80 \%$ after 25 days (Table 3 ). Four month aged Panicum turgidum plants irrigated with water equivalent to $300 \mathrm{~mm}$ produced dense culms with a mean of $3450.6 \mathrm{culm} / \mathrm{m}^{2}$, mean length of $107.3 \mathrm{~cm}$ and mean dry weight equivalent to $4395 \mathrm{~g} / \mathrm{m}^{2}$. For agricultural purposes, propagation of Panicum turgidum by seeds is not recommended as a practical process. However, the seeds can be densely sown in nurseries, then, after the growing seedlings attain considerable size they can be taken and used as transplants that can be utilized for the propagation of the species in the field. Transplants must be kept moist until planting in the field. Clipping of the upper parts of the culms must be done before transplantation to reduce transpiration and to promote tillering. 
Table 1. Effect of thermal treatment of Panicum turgidum seeds (intact) on seedling emergence.

\begin{tabular}{|c|c|c|c|c|c|c|}
\hline \multirow{3}{*}{ Character } & \multirow{3}{*}{ Control } & \multicolumn{4}{|c|}{ Thermal treatment } & \multirow{3}{*}{$\begin{array}{c}\text { Freezing } \\
\left(-6^{\circ} \mathrm{C}\right)\end{array}$} \\
\hline & & \multicolumn{2}{|c|}{$40^{\circ} \mathrm{C}$} & \multicolumn{2}{|c|}{$60^{\circ} \mathrm{C}$} & \\
\hline & & $\begin{array}{c}\text { Dry } \\
\text { seeds }\end{array}$ & $\begin{array}{c}\text { Moistened } \\
\text { seeds }\end{array}$ & $\begin{array}{c}\text { Dry } \\
\text { seeds }\end{array}$ & $\begin{array}{c}\text { Moistened } \\
\text { seeds }\end{array}$ & \\
\hline Germination \% & 14.0 & 22.0 & 10.0 & 5.0 & 6.0 & 5.0 \\
\hline Root length (cm) & 39.8 & 29.3 & 67.3 & 45.9 & 34.7 & 37.0 \\
\hline $\begin{array}{l}\text { Root dry weight } \\
\text { (mg) }\end{array}$ & 92.0 & 59.0 & 298.9 & 290.0 & 193.3 & 287.5 \\
\hline Shoot length $(\mathrm{cm})$ & 10.8 & 8.3 & 7.3 & 6.9 & 8.5 & 5.8 \\
\hline $\begin{array}{l}\text { Shoot dry weight } \\
\text { (mg) }\end{array}$ & 45.0 & 23.0 & 23.9 & 70.0 & 62.2 & 56.2 \\
\hline
\end{tabular}

Table 2. Sprouting of Panicum turgidum transplanted at El-Noubariya on different months.

\begin{tabular}{|c|c|c|c|c|c|c|c|}
\hline \multirow{2}{*}{$\begin{array}{l}\text { Sprouting } \\
\% \text { and } \\
\text { date of } \\
\text { recording }\end{array}$} & \multicolumn{7}{|c|}{ Time of transplanting } \\
\hline & $\begin{array}{c}\text { April } \\
\text { (1994) }\end{array}$ & $\begin{array}{c}\text { July } \\
\text { (1994) }\end{array}$ & $\begin{array}{c}\text { August } \\
(1994)\end{array}$ & $\begin{array}{c}\text { October } \\
(\mathbf{1 9 9 4})\end{array}$ & $\begin{array}{c}\text { November } \\
(1994)\end{array}$ & $\begin{array}{c}\text { December } \\
\text { (1994) }\end{array}$ & $\begin{array}{c}\text { January } \\
\text { (1995) }\end{array}$ \\
\hline 9/8/94 & 51.7 & 12.4 & - & - & - & - & - \\
\hline $23 / 8 / 94$ & 49.4 & 17.0 & - & - & - & - & - \\
\hline $30 / 8 / 94$ & 51.7 & 20.3 & 6.6 & - & - & - & - \\
\hline $29 / 9 / 94$ & 52.3 & 24.5 & 15.0 & - & - & - & - \\
\hline $4 / 10 / 94$ & 55.2 & 28.7 & 25.8 & - & - & - & - \\
\hline $21 / 12 / 94$ & 50.5 & 27.7 & 25.8 & 50.5 & 18.8 & 0.0 & 0.0 \\
\hline $4 / 1 / 95$ & 50.5 & 27.7 & 25.8 & 47.4 & 11.0 & 0.0 & 0.0 \\
\hline $26 / 1 / 95$ & 50.5 & 27.7 & 25.8 & 47.4 & 8.0 & 0.0 & 0.0 \\
\hline
\end{tabular}

Table 3. Emergence of Panicum turgidum seedlings at the green house of Cairo University.

\begin{tabular}{|c|c|c|c|c|c|c|c|c|c|}
\hline \multicolumn{10}{|c|}{$\%$ of emerged seeds after ......days } \\
\hline 5 & 6 & 7 & 8 & 9 & 12 & 15 & 18 & 25 & 30 \\
\hline 10 & 23 & 23 & 54 & 60 & 68 & 79 & 79 & 80 & 80 \\
\hline
\end{tabular}




\section{Response of Panicum turgidum to different water treatments Biomass}

1- The biomass (productivity) of plants growing under different water treatments (Table 5) shows the same general trend, being small in the young stages of growth and increased considerably with age of plants. For example, biomass amounting to $2.8,2.9$ and $7.4 \mathrm{~g} / \mathrm{m}^{2}$ was estimated at the first cutting for plants growing under water treatments 1, 2 and 3, respectively. Six months latter (third cutting), the corresponding values increased to $75.7,49.3$ and $144 \mathrm{~g} / \mathrm{m}^{2}$ for plants growing under water treatments 1,2 and 3, respectively.

The biomass attained maximum values at different stages. Biomass of 177.2 and $778.2 \mathrm{~g} / \mathrm{m}^{2}$ was attained at the eighth cutting for plants of treatment (1) and treatment (3), respectively. Whereas a biomass of $124.2 \mathrm{~g} / \mathrm{m}^{2}$ was recorded for plants of treatment (2) at the seventh cutting. The high biomass value $\left(778.2 \mathrm{~g} / \mathrm{m}^{2}\right)$ that obtained in case of plants growing under treatment (3), at the final cutting, is significantly higher than the corresponding values in the two other treatments and is also significantly higher than the values of treatment (3) in the preceding cuttings.

2- The obtained data (Table 5) show that within the three tested water regimes, the biomass of the fourth cutting (growth period during July), was lower than that of the third and fifth ones (growth period during May, June and August). Moreover, the biomass (dry weight) decreased in the sixth cutting (growth period during September) than in the fifth cutting (growth period during August) and the seventh cutting (growth period from October to March). This reduction may be attributed to the decrease in the amount of water received before these cuttings, also may be due to the high clipping intensities preceding these cuttings. Air temperature during the growth periods may have significant effect. 
Table 4. Some characteristic features of a four month old Panicum turgidum seedlings.

\begin{tabular}{|c|c|c|c|}
\hline $\begin{array}{c}\text { Mean dry weight } \\
\text { Biomass }\left(\mathrm{gm} / \mathrm{m}^{2}\right)\end{array}$ & $\begin{array}{c}\text { Mean number of } \\
\text { culms/m² }\end{array}$ & $\begin{array}{c}\text { Mean number of } \\
\text { culms/plant }\end{array}$ & $\begin{array}{c}\text { Mean length of } \\
\text { culms (cm) }\end{array}$ \\
\hline 4395.5 & 3450.6 & 21.3 & 107.3 \\
\hline
\end{tabular}

Table 5. Productivity $\left(\mathrm{g} / \mathrm{m}^{2}\right.$, mean \pm s.d.) of Panicum turgidum growing under different water treatments.

\begin{tabular}{|c|c|c|c|}
\hline \multirow{2}{*}{$\begin{array}{l}\text { Cutting number } \\
\text { and date }\end{array}$} & \multicolumn{3}{|c|}{ Productivity $\left(\mathrm{g} / \mathrm{m}^{2}\right)$} \\
\hline & Treat. 1 & Treat. 2 & Treat. 3 \\
\hline $\begin{array}{c}1^{\text {st }} \text { cut. } \\
28-11-96\end{array}$ & $2.8 \pm 0.6$ & $2.9 \pm 1$ & $7.4 \pm 3.5$ \\
\hline $\begin{array}{l}2^{\text {nd }} \text { cut. } \\
1-5-97\end{array}$ & $8 \pm 3.6$ & $5.7 \pm 2.3$ & $16.7 \pm 15.3$ \\
\hline $\begin{array}{l}3^{\text {rd }} \text { cut. } \\
1-7-97\end{array}$ & $75.7 \pm 48.7$ & $49.3 \pm 24.1$ & $144 \pm 104.4$ \\
\hline $\begin{array}{l}4^{\text {th }} \text { cut. } \\
1-8-97\end{array}$ & $71.0 \pm 42.8$ & $38.9 \pm 11.4$ & $63.1 \pm 39.5$ \\
\hline $\begin{array}{l}5^{\text {th }} \text { cut. } \\
1-9-97\end{array}$ & $143.6 \pm 90$ & $49.9 \pm 35.8$ & $93.1 \pm 41.1$ \\
\hline $\begin{array}{l}6^{\text {th }} \text { cut. } \\
1-10-97\end{array}$ & $55.5 \pm 30$ & $42.1 \pm 26.7$ & $98.1 \pm 63.2$ \\
\hline $\begin{array}{l}7^{\text {th }} \text { cut. } \\
1-4-98\end{array}$ & $167.7 \pm 170.5$ & $124.2 \pm 39.3$ & $471.3 \pm 288.9$ \\
\hline $\begin{array}{l}8^{\text {th }} \text { cut. } \\
1-8-98\end{array}$ & $177.2 \pm 220.7$ & $52.2 \pm 51.2$ & $778.2 \pm 540.2$ \\
\hline
\end{tabular}


3- Generally, the biomass per month increased in the warm season (extending from April to October with mean air temperature ranging between 21.2 and $27.8{ }^{\circ} \mathrm{C}$ ) and decreased in the cold season (extending from November to March with mean air temperature ranging between 13.6 and $19{ }^{\circ} \mathrm{C}$ ). The highest dry weight amounting to (143.6 and $49.9 \mathrm{~g} / \mathrm{m}^{2}$ month) was obtained in the fifth cutting (growth period during August) in case of treatment (1) and (2) respectively. In case of treatment (3), the highest dry weight (98.1 $\mathrm{g} / \mathrm{m}^{2}$ months) was recorded in the sixth cutting (growth period during September).

4- The results show that the dry weight obtained from plants of treatment (1) is greater than that of treatment (2). However, significant differences were only found in the fifth cutting.

5- The data evinced that in the fourth and fifth cuttings (growth period during July and August), the biomass of plants of treatment (1) was higher than that of the two other treatments, the values of biomass were $143.6,49.9$ and $93.1 \mathrm{gm} / \mathrm{m}^{2}$ in treatments (1), (2) and (3) respectively.

\section{Seed production (number of seeds per unit area)}

Data illustrated in (Table 6) reveal that, fruiting of Panicum turgidum started gradually from April and increases to attain its maximum intensity

during August. The maximum number of seeds amounting to $26979 \mathrm{seed} / \mathrm{m}^{2}$ was recorded in plants of treatment (3). It is to be noted that, at the eighth cutting, treatments 1,2 and 3 have significantly higher values of the number of seeds per square meter than the preceding cuttings of these treatments. These results may be attributed to the greater length of cultivation period (from April to July during the warm season) giving greater opportunity to flower and seed production in the three treatments. Moreover, the monthly produced seeds per square meter and monthly formed fruiting culms were higher at the fifth cutting (growth period during August) than those estimated at the fourth and sixth cuttings (growth period during July and September; respectively). These values were 52, 240.7 and 1770.4 $\mathrm{seed} / \mathrm{m}^{2}$.month and 2.4, 5.6 and 12.7 fruiting culms\% per month for treatment 1, 2 and 3; respectively. 


\section{Vegetative growth criteria (number of culms per unit area)}

Data illustrated in (Table 7) reveal the following:

1. At the first cutting (120 days after sowing), the number of culms $/ \mathrm{m}^{2}$ of plants growing under different water regimes was about four times higher than those recorded at the second cutting $(5$ months after the first cutting). For example, the number of culms decreased from 182 to 44.9 , from 215.4 to 45 and from 234.8 to $60.1 \mathrm{culm} / \mathrm{m}^{2}$ at the first and second cuttings for plants of treatments 1,2 and 3, respectively. The reduction in the number of culms $/ \mathrm{m}^{2}$ was observed also in plants of he fourth and fifth cuttings which was much lower than that obtained at he third cutting. These results evidences that during the first year, clipping of the plant inhibits the formation of culms.

2. The maximum number of culms was recorded in summer months (July and August) amounting to $36.7,305.3$ and $629.2 \mathrm{culm} / \mathrm{m}^{2}$ for plants of treatments 1,2 and 3 , respectively.

3. In most of the cuttings, plants of treatment (1) have higher number of culms per square meter than those growing under treatment (2), with significant differences in the fourth cutting. Plants of treatment (3) have the highest values of the number of culms per square meter than those of the two other treatments. On the other hand, in the eighth cutting, plants of treatment (1) have higher number of culms in spite of the lower productivity values.

4. In all treatments, the length of the produced culms (Table 7) show a considerable increase in the successive cuttings, with a maximum length of $72.38,68.76$ and $98.66 \mathrm{~cm}$ for plants of treatments 1,2 and 3 , respectively. It is interesting to mention that plants of treatment (1) have higher values in both number and length of culms than the corresponding values in case of treatment (2).

5. The number of culms per square meter per month and the length of culms per month show highest values in the warm season. Highest values of the number of culms per square meter per month were obtained in the sixth cutting (growth period during September) amounting to $302.5,254.4$ and $378.8 \mathrm{culm} / \mathrm{m}^{2} / \mathrm{month}$ in plants of treatments 1,2 and 3 , respectively.

6. Data illustrated in (Table 8) show that water content of Panicum turgidum plants growing under the three tested water treatments 
shows no significant differences. Water content ranged between 66.1 and $76.3 \%$ in plants of treatment (1), from 63.5 to $76.4 \%$ in plants of treatment (2) and it ranged between 67.2 and $76.3 \%$ in plants of treatment (3).

All studied growth parameters seemed to be increased during the warm season. Generally, the highest values of the biomass (dry weight), seed production per month and length of culms per month were obtained in the fifth cutting (growth period during August) in the three treatments. However, the highest number of culms per square meter per month was recorded in the sixth cutting (growth period during September) in the three treatments. In the majority of the investigated cuttings, the biomass and growth criteria of treatment (1), receiving the lowest amount of' water, were slightly higher than those of treatment (2), receiving higher amount of water. On the other hand, plants of treatment (2) have higher seed production than treatment (1).

Table 6. Seed Production (fruiting culms $\%$ and Number of seeds $/ \mathrm{m}^{2}$; mean \pm s.d.) of Panicum turgidum cultivated under different water treatments.

\begin{tabular}{|c|c|c|c|c|c|c|}
\hline \multirow{2}{*}{$\begin{array}{c}\text { Cutting } \\
\text { number and } \\
\text { date }\end{array}$} & \multicolumn{3}{|c|}{ Fruiting culms \% } & \multicolumn{3}{|c|}{ Number of seeds $/ \mathrm{m}^{2}$} \\
\hline & Treat. 1 & Treat.2 & Treat.3 & Treat.1 & Treat.2 & Treat.3 \\
\hline $\begin{array}{c}1^{\text {st }} \text { cut. } \\
28-11-96\end{array}$ & $\mathbf{0}$ & $\mathbf{0}$ & $\mathbf{0}$ & $\mathbf{0}$ & $\mathbf{0}$ & $\mathbf{0}$ \\
\hline $\begin{array}{l}2^{\text {nd }} \text { cut. } \\
1-5-97\end{array}$ & $0.8 \pm 1.8$ & $0.7 \pm 1.6$ & $2.8 \pm 2.7$ & $20 \pm 44.72$ & $31.2 \pm 69.76$ & $110 \pm 151.42$ \\
\hline $\begin{array}{l}3^{\text {rd }} \text { cut. } \\
1-7-97\end{array}$ & $0.8 \pm 1.7$ & $2.6 \pm 2.5$ & $11.7 \pm 8.6$ & $11.2 \pm 25.04$ & $752.8 \pm 1645$ & $1603.7 \pm 1853.7$ \\
\hline $\begin{array}{l}4^{\text {th }} \text { cut. } \\
1-8-97\end{array}$ & $0.9 \pm 2.1$ & $3 \pm 2.8$ & $8.1 \pm 4.9$ & $1.6 \pm 3.57$ & $217.2 \pm 384.4$ & $832.3 \pm 961.5$ \\
\hline $\begin{array}{l}5^{\text {th }} \text { cut. } \\
1-9-97\end{array}$ & $2.4 \pm 3.3$ & $5.6 \pm 9.6$ & $12.7 \pm 12.4$ & $52.0 \pm 72.2$ & $240.7 \pm 329.6$ & $1770.4 \pm 1685.3$ \\
\hline $\begin{array}{l}6^{\text {th }} \text { cut. } \\
1-10-97\end{array}$ & $1 \pm 2.2$ & $2.3 \pm 3.2$ & $8.9 \pm 0.1$ & $19.2 \pm 42.9$ & $68.4 \pm 93.7$ & $227.8 \pm 235.2$ \\
\hline $\begin{array}{l}7^{\text {th }} \text { cut. } \\
1-4-98\end{array}$ & $32.4 \pm 77.3$ & $29.3 \pm 11.3$ & $62.7 \pm 12.5$ & $866.6 \pm 1182.7$ & $1747.9 \pm 1726.8$ & $10694.2 \pm 7518.7$ \\
\hline $\begin{array}{l}8^{\text {th }} \text { cut. } \\
1-8-98\end{array}$ & $38.6 \pm 14.8$ & $25.2 \pm 16.7$ & $74.8 \pm 25$ & $1164.8 \pm 1338.7$ & $3028 \pm 2625.1$ & $26979 \pm 26075$ \\
\hline
\end{tabular}


Reproductive Ecology of Panicum turgidum Forssk.

Table 7. Growth criteria (Number of culms per square meter and Length of culms; mean \pm s.d.) of Panicum turgidum cultivated under different water treatments.

\begin{tabular}{|c|c|c|c|c|c|c|}
\hline \multirow{2}{*}{$\begin{array}{c}\text { Cutting } \\
\text { number and } \\
\text { date }\end{array}$} & \multicolumn{3}{|c|}{ Number of culms $/ \mathrm{m}^{2}$} & \multicolumn{3}{|c|}{ Length of culms $(\mathrm{cm})$} \\
\hline & Treat.1 & Treat.2 & Treat.3 & Treat.1 & Treat.2 & Treat.3 \\
\hline $\begin{array}{c}1^{\text {st }} \text { cut. } \\
28-11-96\end{array}$ & $182 \pm 22.79$ & $215.4 \pm 26.5$ & $234.8 \pm 20.2$ & $12.77 \pm 3.91$ & $11.45 \pm 4.88$ & $13.78 \pm 45$ \\
\hline $\begin{array}{l}2^{\text {nd }} \text { cut. } \\
1-5-97\end{array}$ & $44.9 \pm 8.1$ & $45.4 \pm 10.3$ & $60.1 \pm 12.4$ & $12.17 \pm 1.44$ & $12.17 \pm 1.44$ & $14.45 \pm 2.67$ \\
\hline $\begin{array}{l}3^{\text {rd }} \text { cut. } \\
1-7-97\end{array}$ & $426.7 \pm 185.7$ & $305.3 \pm 63$ & $434 \pm 144.14$ & $30.5 \pm 9.16$ & $23.71 \pm 2.85$ & $30.25 \pm 7.84$ \\
\hline $\begin{array}{l}4^{\text {th }} \text { cut. } \\
1-8-97\end{array}$ & $89.2 \pm 20.84$ & $57 \pm 9.96$ & $90.2 \pm 31.88$ & $38.31 \pm 9.73$ & $30.33 \pm 6.45$ & $34.12 \pm 8.02$ \\
\hline $\begin{array}{l}5^{\text {th }} \text { cut. } \\
1-9-97\end{array}$ & $99.7 \pm 31.56$ & $63.9 \pm 22.9$ & $115.5 \pm 53.85$ & $53.44 \pm 6.49$ & $38.68 \pm 9.64$ & $51.46 \pm 13.57$ \\
\hline $\begin{array}{l}6^{\text {th }} \text { cut. } \\
1-10-97\end{array}$ & $302.5 \pm 107.3$ & $254.4 \pm 122.7$ & $378.8 \pm 215.3$ & $41.21 \pm 13.62$ & $39.82 \pm 14.93$ & $43.42 \pm 4.52$ \\
\hline $\begin{array}{l}7^{\text {th }} \text { cut. } \\
1-4-98\end{array}$ & $383.2 \pm 259.9$ & $284.2 \pm 56.6$ & $629.2 \pm 282.9$ & $46.95 \pm 24.29$ & $56.74 \pm 15.1$ & $63.32 \pm 20.31$ \\
\hline $\begin{array}{l}8^{\text {th }} \text { cut. } \\
1-8-98\end{array}$ & $436 \pm 345.9$ & $146 \pm 59.8$ & $97 \pm 621.8$ & $72.38 \pm 7.17$ & $68.76 \pm 10.6$ & $98.66 \pm 6.6$ \\
\hline
\end{tabular}

Table 8. Water content (mean \pm s.d.) of Panicum turgidum cultivated, under different water treatments.

\begin{tabular}{|c|c|c|c|}
\hline \multirow{2}{*}{$\begin{array}{l}\text { Cutting number } \\
\text { and date }\end{array}$} & \multicolumn{3}{|c|}{ Productivity $\left(\mathrm{g} / \mathrm{m}^{2}\right)$} \\
\hline & Treat. 1 & Treat. 2 & Treat. 3 \\
\hline $\begin{array}{c}1^{\text {st }} \text { cut. } \\
28-11-96\end{array}$ & $73.4 \pm 11.9$ & $75.6 \pm 2.5$ & $71.2 \pm 9.5$ \\
\hline $\begin{array}{l}2^{\text {nd }} \text { cut. } \\
1-5-97\end{array}$ & $73.2 \pm 1.8$ & $63.5 \pm 20.8$ & $72.9 \pm 2.2$ \\
\hline $\begin{array}{l}3^{\text {rd }} \text { cut. } \\
1-7-97\end{array}$ & $73.3 \pm 1.9$ & $72.1 \pm 0.9$ & $74.6 \pm 1.8$ \\
\hline $\begin{array}{l}4^{\text {th }} \text { cut. } \\
1-8-97\end{array}$ & $76.3 \pm 1.8$ & $71.8 \pm 8.7$ & $73.7 \pm 9.9$ \\
\hline $\begin{array}{l}5^{\text {th }} \text { cut. } \\
1-9-97\end{array}$ & $73.7 \pm 2.8$ & $75.7 \pm 2.8$ & $76.2 \pm 2.2$ \\
\hline $\begin{array}{l}6^{\text {th }} \text { cut. } \\
1-10-97\end{array}$ & $73 \pm 3.2$ & $76.4 \pm 2.8$ & $76.3 \pm 4.4$ \\
\hline $\begin{array}{l}7^{\text {th }} \text { cut. } \\
1-4-98\end{array}$ & $70.5 \pm 2.1$ & $69.5 \pm 1$ & $71.1 \pm 0.8$ \\
\hline $\begin{array}{l}8^{\text {th }} \text { cut. } \\
1-8-98\end{array}$ & $66.1 \pm 1.1$ & $64.3 \pm 8.3$ & $67.2 \pm 3.9$ \\
\hline
\end{tabular}




\section{Discussion}

Panicum turgidum withstands a wide range of climatic conditions. In Egypt, it has been recorded in both arid and extreme arid sub-climatic region of Egypt extending from the Mediterranean coastal region (north of Egypt) to Gebel Elba and Wadi Halfa (south of Egypt), on the SudanEgyptian border

There are increasing needs for the rehabilitation of forage and sand binder species, Panicum turgidum seems to be among the most suitable indigenous plants that must be taken into consideration. Due to its widely spread and deeply penetrated root system, the investigated species is used as a sand binder plant (Williams and Farias, 1972). The species has a great potential for survival under saline conditions (Ismail et al., 1983) and is used for the stabilization of moving sand dunes to stop desert encroachment. It is successfully rehabilitated in many cases e.g. during the regeneration of the Thar Desert in India (Sinha, 1997).

Panicum turgidum is a highly palatable fodder plant with a considerable range value providing green fodder in summer months where most of the fodder plants suffer from the harsh prevailing environmental conditions (Batanouny, 1979; Zahran and Willis, 1992; Oathan, 1997). It was also found that Panicum turgidum had better value as a forage plant than Lasiurus scindicus and Pennisetum divisum species, when the growth characteristics and energy content were taken as a measure of the grazing value (Hegazy and El-Khateeb, 2001).

In nature, the most critical stage in the life cycle of a plant species is the germination of its seeds, which may control its propagation and distribution. A successful germination process is the first step in plant establishment. In case of Panicum turgidum, highst germination percent was achieved at relatively high temperatures $\left(35^{\circ} \mathrm{C}\right)$. Not only high temperature is necessary for a successful germination of Panicum turgidum seeds, but also an adequate water supply is required, a condition which does not occur in the natural habitats supporting the species in the Egyptian desert unless exceptionally. This explains why the seedlings of the studied species are rarely met with in the natural habitat, consequently the reproduction and spreading of this species takes place mainly vegetatively and seedlings rarely occur.

The alternation of day and night conditions may have a role in breaking dormancy of seeds of many species. The present work evidences that germination of dehusked Panicum turgidum seeds attained its maximum 
value of $84 \%$ under alternated temperatures of $20-30^{\circ}$ C. Seed germination tests revealed also that when germination was tested using dehusked seeds, lower temperatures were required $\left(10-25^{\circ} \mathrm{C}\right)$ with maximum germination of $61 \%$. Al-Khateeb (2006) proved that intermediate degrees of temperature, $15-25^{\circ} \mathrm{C}$ and $20-30^{\circ} \mathrm{C}$, resulted in a significant increase in biomass accumulation of Panicum turgidum.

The significance of a specific morphology of a diaspore is evident when the normal and natural form is altered (Booth \& Haferkamp, 1995). The increase in seed mortality by removal of the seed cover reveals the importance of this cover for a successful germination. This finding has been observed by many other authors (Simpson, 1952; Sankary and Barbour, 1972; Peart, 1979; Booth and Shuman, 1983). Threshing of Haloxylon articulatum and the winter fat plant (Eurotia Lanata) had improved germination but reduced seedling establishment (Sankary and Barbour, 1972; Booth \& Shuman, 1983). Removal of the diaspore appendages of certain grasses may also reduce their establishment (Simpson, 1952; Peart, 1979).

The reduced establishment of the seedlings obtained from the denatured seeds may be attributed partially to injury of seed embryos during threshing (Booth, 1984 and 1987), or due to the loss of assisting functions by the parts removed in threshing (Sankary \& Barbour, 1972; Peart, 1979).

Panicum turgidtun seeds germinate successfully under relatively high temperatures, thus, improvement of seed germination by heat treatment is possible. The increase of germination of the seeds exposed to temperature of $40^{\circ} \mathrm{C}$ before their germination may be due to the partial removal of this dormancy, while the decrease in germination of the seeds treated with temperature of $60^{\circ} \mathrm{C}$ before germination may be resulted from the inhibition of some physiological processes of the seed. On the other hand, freezing treatment has no effect on seed germination.

Knowledge of the proper method for propagation of such forage species and the best time for transplantation is of prime importance for land reclamation and reforestation of degraded rangelands. Generally, seedlings originating from sown seeds need several weeks to be established. On the other hand, plants established from cuttings started with already expanded leaves and reserve food in rhizomes. This is reflected on the biomass of the populations where the biomass of plants propagated by cuttings is greater than that of plants propagated by seeds. 
Propagation of the studied species by seeds was promising. Seedling emergence attained maximum value during the hot summer months, especially from May to August. However, propagation by transplants was favoured in months with moderate temperatures so as not to cause excessive loss of water and drying of transplants.

For economic purpose, propagation of Panicum turgidum by transplants is recommended especially whenever twice month irrigation is available even with a least amount of water.

In the present investigation, the response of Panicum turgidum to different water treatments was studied in order to evaluate how this important grass survive under the harsh climatic conditions prevailing in the Egyptian desert, moreover to estimate the reproductive strategies of this species under different conditions. Cultivation of Panicum turgidum plants under different water treatments showed that this species was greatly influenced by the amount of available water. Growth increased whenever the amount of water increased. The increase of growth is reflected mostly on the biomass, the tillering capacity and the seed output.

All the studied parameters have been increased during the warm season. Generally, highest values of biomass production (dry weight per month), seed production per month and length of culms were obtained at the fifth cutting (September). This trend was observed in plants growing under the different water treatments. However, the highest number of culms per square meter per month was recorded at the sixth cutting (October).

The effect of water supply on the growth criteria of Panicum turgidum was more pronounced at the seventh and eighth cuttings, at the seventh cutting (April), the obtained biomass $\left(471.3 \mathrm{~g}\right.$ dry weight $\left./ \mathrm{m}^{2}\right)$, value of fruiting culms $(62.7 \%)$, and the number of seeds per square meter (10694.2), were significantly higher in treatment (3) receiving higher water supply than in the two other treatments. At the eighth cutting (August), the corresponding values were $778.2 \mathrm{~g} / \mathrm{m}^{2}$ for dry weight productivity, $74.8 \%$ for fruiting culms and 26979 for the number of seeds per square meter.

The present work evidences the lack of parallelism between the amount of water supply and that of plant water content of the studied species, a result which may be explained by the absence of control on water loss and the high diurnal variation in water potential of Panicum turgidum (Oathan, 1997).

It is believed that grazing increased tillers number and grain yield in some species (Mazid \& Hallagian, 1983). Busso \& Richards (1995), 
Reproductive Ecology of Panicum turgidum Forssk.

suggested that when conditions allow, increased tillering is a common response of grasses to grazing at an early stage of development, the increase most probably resulted from the removal of the main culm and primary tillers with their associated apical dominance.

Mohammad et al. (1982) suggests that growth and survival should be enhanced by light to moderate grazing under drought conditions, as a result of the decreased amount of transpiring surface. On the other hand, (Brown, 1995) reported that the removal of vegetative and reproductive tissue during the growing season by either grazing or clipping (which presumably mimics herbivory) can have significant effects, either direct or indirect on physiological processes and morphological development that affect plant water relations and ultimately plant survival in harsh range land environments.

The reduction of growth is greater under the combination of drought and clipping (Mohammad et al., 1982; Busso \& Richards, 1995), especially under severe grazing (Weaver \&Albertson, 1939) and/or severe water stress (Cook et al., 1958; Mohammad et al., 1982).

Panicum turgidurn responded to water treatments by different energy allocation strategies. Plants that had received the lowest amount of water (treatment 1), produced slightly more tillers $\left(436 \mathrm{culm} / \mathrm{m}^{2}\right)$ with higher length $(72.38 \mathrm{~cm})$ than treatment $(2)$, receiving higher amount of water, in which $146 \mathrm{culm} / \mathrm{m}^{2}$ with stem length of $68.76 \mathrm{~cm}$ were obtained at the final cutting. On the other hand, plants of treatment (2) produced more seeds amounting to $3028 \mathrm{seed} / \mathrm{m}^{2}$. This value decreased to $1164.8 \mathrm{seed} / \mathrm{m}^{2}$ in treatment (1). These data indicated that plants of treatment (2) may owed the smaller size (lower number of culms per square meter and lower length) mainly to investment of resources in producing flowering culms and grains than in vegetative tillers. Meanwhile, plants receiving the highest amount of water (treatment 3) had a relative equilibrium between the vegetative reproduction and the seed output.

The allocation of energy to various activities during the development of an organism has ecological significance. The process of growth, development and reproduction in a plant may be seen as a strategy of allocation of limited resources. Some species exhaust more energy on vegetative propagules, others exhaust relatively large proportions of their energy on perennating organs or on height expenditure or competitive ability rather on potential multiplication, others may expend significant 
proportion of their resources on extensive root systems or on the development of spines, defense chemicals or large and attractive flower parts (Cody, 1966; Harper, 1967).

The quality program of energy allocation by an organism is an essential feature of its life cycle strategy; in particular the energy allocated to reproductive organs, both vegetative and seed, is of great interest in species that possess both types of reproduction (Tripathi \& Harper, 1973).

The emergence, survival and establishment of seedlings constitute key factors in the maintenance and recovery of vegetation cover (Harper, 1977 and Chambers et al., 1987). In arid and semiarid ecosystems, the success of seedling survival is strongly coupled with water availability in the soil (Beatley, 1974; Herbel, 1979; Vallentine, 1980; Mach and Pyke, 1984 and Flowler, 1986). In case of Panicum turgidum, a successful germination requires the combination of a high temperature $\left(30-35^{\circ} \mathrm{C}\right)$ and an adequate water supply, a condition which is rarely found in the Egyptian desert conditions where rain often falls in winter months with low temperature. Therefore, Panicum turgidum seedlings are rarely found in the desert conditions and the main reproductive strategy of the species is the vegetative one.

The relationships between the examined species of Lupinus based on the analysis of seed protein data and expressed as a NJ and UPGMA trees is congruent with their systematic treatments and ecogeoraphic distribution. The New World species are clearly separated together from the Old World species, this separation is clearly supported by the morphological and cytological diversity among the two groups (Dunn \& Gillett, 1966; Dunn, 1984; Turner, 1995). Most of the New World species display a common chromosome number of $2 n=48$ (Phillips, 1957; Dunn \& Gillett, 1966), with some occasional polyploid individuals having $2 n=96$ (Phillips, 1957). The Old World species, on the other hand, exhibit variable chromosome numbers ranging from $2 n=32$ to $2 n=52$. (Gladstones, 1984; Plitmann \& Heyn, 1984; Plitmann \& Pazy, 1984; Carstairs et al., 1992).The separation of the New and Old World lupines as two distinct groups was also indicated by evidence obtained from the chloroplast RFLP (Badr et al., 1994) and by variation in internal transcript spacer sequence (Ainouche \& Bayer, 1999).

The grouping of the ten samples representing six species of the New World lupines as a single group is congruent with the difficulties to separate 
the New World species of Lupinus due to the few diagnostic features to separate them. However, the six species are clearly delimited as separate identities with high levels of dissimilarity between them particularly in the UPGMA tree. In the NJ tree, high levels of dissimilarity are observed between $L$. sativus and $L$. sylvestris and the cluster comprised of $L$. mutabilis, L. succulentus, L. elegans and L. hartwegii. However, with data on the small number of the New World species examined in the present study, it is difficult to discuss further the relationship of the New World lupines.

Meanwhile, 17 samples representing eight of the Old World species have been included in this study allowing detailed discussion of their relationships. The smooth-seeded lupines of the Old World, are delimited as a distinct group from the rough seeded species, these are all Mediterranean, and morphologically well defined species and have been recognized as different sections (Gladstones, $1974 \& 1984$ ) The separation of the smoothseeded and rough-seeded species is largely in accordance with biochemical data from alkaloids (Wink et al., 1995), leaf flavonoids (Williams et al., 1983), electrophoretic pattern of seed globulins (Przybylska \& ZimniakPrzybylska, 1995), isozymes polymorphism (Wolko \& Weeden, 1989; 1990) and nuclear DNA content variation (Naganowska et al., 2003).

Within the smooth-seeded species, variation in seed protein data supports the sectional delimitation of the studied species. The analysis of these data, by the UPGMA tree building method, distinguished L. albus, $L$. angustifolius, L. micranthus that have been placed in separate sections (Albi, Angustifoli, and Micranthi respectively), and grouped $L$. luteus with $L$. hispanicus that have been placed together in sect. Lutei. The separation of $L$. albus $(2 n=50)$ and $L$. angustifolius $(2 n=40)$ is congruent with the variation in their chromosome number (Gladstones, 1974 and 1984; Amaral Franco \& Pinto da Silva, 1978). However, L. micranthus, (sect. Micranthi) and Lupinus luteus and L. hispanicus (sect. Lutei) all have 2n=52 (Kazimierski, 1982); the latter two species were also found as sister samples, well differentiated from other smooth seeded species by seven nucleotide changes in the ITS sequence (Ainouche \& Bayer, 1999).

Despite their differences in morphology and cytology, sections Lutei and Angustifoli were found as members of a monophyletic group, based on the analysis of variation in ITS sequence (Ainouche \& Bayer, 1999). This is reflected in the NJ tree presented in this study and was also seen in the tree 
based on $r b c L$ analysis (Käss \& Wink, 1997). L. luteus was suggested as being closer to L. micranthus based on similar chromosome numbers and some morphological affinities (Gladstones, 1984 and 1998), a relationship that is not corroborated by ITS results (Ainouche \& Bayer, 1999) or by crossing data (Roy\& Gladstones, 1988; Gupta et al., 1996). Lupinus luteus is represented on both sides of the Mediterranean and has been considered the most derived species of the smooth seeded clade with respect to ITS sequence (Ainouche \& Bayer, 1999). Gladstones (1974) suggested the Iberian Peninsula as the place of origin of sect. Lutei, whereas that of sect. Angustifoli is somewhere in the Mediterranean.

The position of $L$. micranthus in relationship to other species has been the subject of debate in the literature. Investigations based on flavonoids (Williams et al., 1983), serology (Cristofolini, 1989), and isozymes (Wolko \& Weeden, 1989; 1990) indicated an intermediate position of this species between the smooth-seeded and the rough-seeded lupines of the Old World. This is clearly supported by the position of L. micranthus in the UPGMA tree based on our seed protein analysis.

The rough-seeded lupines have been delimited as a separate group from the smooth-seeded species in both the NJ and UPGMA trees. This is supported by remarkable morphological homogeneity of this group and has been demonstrated by various sources of data including seed coat texture (Heyn \& Herrnstadt, 1977); alkaloids (Wink et al., 1995; Ainouche et al., 1996), flavonoids (Williams et al., 1983), seed globulin proteins (Przybylska \& Zimniak-Przybylska, 1995), protein serology (Cristofolini, 1989 ) and isozymes (Wolko \& Weden, 1989 \&1990). The analysis of seed protein data presented here added to the above evidence support the proposition to recognize the rough-seeded species as a separate section Scabrispermae Plitm. \& Heyn (Plitmann \& Heyn, 1984) that was also strongly reinforced by nrDNA evidence (Käss \& Wink, 1997; Ainouche \& Bayer, 1999).

The rough seeded species are differentiated into two clusters; one includes the three samples of $L$. consentinii $(2 n=32)$ and the other comprises the two samples of $L$. pilosus $(2 n=42)$ and atlanticus $(2 n=38)$. The relationships as expressed by seed protein data may be regarded congruent with their cytological differences. The rough-seeded lupines, which are distributed in the eastern Mediterranean region, were shown to be reproductively isolated (Roy \& Gladstones, 1988; Carstairs et al., 1992), although genome similarities were found between $L$. pilosus and $L$. 
atlanticus (Gupta, et al., 1996). Meanwhile, species originating from the arid regions of North Africa, L. atlanticus and L. digitatus, both with $2 n=36$, were found as sister samples in the ITS phylogeny presented by Ainouche \& Bayer (1999), but were found slightly more distantly related in the ITS sequence data of Käss \& Wink (1997). Nevertheless, it has been demonstrated that these two species intercross successfully and have a greater homology of chromosomes than to any other rough-seeded species (Roy \& Gladstones, 1988; Carstairs, et al., 1992; Gupta et al., 1996).

The Mediterranean, L. cosentinii $(2 n=32)$ was found to exhibit an identical ITS sequence to that of the hypothesized recent common ancestor of the rough-seeded lupines. This is in agreement with ITS results of Käss \& Wink (1997) but not with their $r b c L$ data where L. cosentinii appeared to accumulate relatively more mutations (Käss \& Wink, 1997). This species was found more closely related to $L$. atlanticus and $L$. digitatus than to $L$. pilosus and $L$. palaestinus with regard to chromosome numbers and interspecific crossing ability (Roy \& Gladstones, 1988; Carstairs, et al., 1992). This evidence supports the results based on seed protein data, as reported here, where the three samples representing $L$. cosentinii are clearly isolated from the other rough-seeded L. pilosus and L. atlanticus in both the NJ and UPGMA trees.

\section{References}

Al-Khateeb, S.A. 2006. Effect of salinity and temperature on germination, growth and ion relations of Panicum turgidum Forssk. Bioresource Technology 97: 292-298.

Batanouny, K. H. 1968. Formation of phytogenic hillocks, I- Plants forming phytogenic hillocks. Acta Botanica Scientiarum Hungaricae, Tomus 14: 243-252.

1969. Formation of phytogenic hillocks, II- Rooting habit of plants forming phytogenic hillocks. Acta Botanica Scientiarum Hungaricae 15: 1-18.

1979. The desert vegetation in Egypt. Cairo Univ. Afr. Stud. Rev. Sp. Publ. 1: 9-37.

- 1981. Ecology and Flora of Qatar. The Alden Press, Oxford. Qatar Univ. 243pp 

world. In National Biodiversity planning in the Arab World (eds. R. Hamzah, M. N. Alaa El-Din and S. A. Mohammed), pp. 121-142.

Beatley, J. C. 1974. Effects of rainfall and temperature on the distribution and behavior of Larrea tridentata (creosote-bush) in Mojave desert of Nevada. Ecology 55: 245-261.

Booth, D. T. 1984. Threshing damage to radicle apex affects geotropic response of winter fat. J. Range Manage. 37: 222-225.

- 1987. Contributions to The Reproductive Ecology of Winter Fat Eurotia lanata (Pursh) Moq. with Notes on Direct Seedling Methods. Ph. D. Diss. Univ. of Wyoming, Laramie, WY. Diss. Abstr. 48: 1568-B.

and Schuman, G. E. 1983. Seedbed ecology of winter fat: Fruit versus threshed seeds. J. Range Manage. 36: 387-390.

and Haferkamp, M. R. 1995. Morphology and Seedling Establishment. In: D.J. Bedunah and R. E. Sosebee (eds.), Wild Plants: Physiological Ecology and Developmental Morphology. Society for Range Management, U. S. A.

Brown, R. W. 1995. The water relations of Range Plants: Adaptations to water deficits. In: D. J. Bedunah and R. E. Sosebee (eds), Wildland plants: Physiological Ecology and Developmental Morphology. Society of Range for Range Management, U.S.A.

Busso, C. A. and Richards, J. H. 1995. Drought and clipping effects on tiller demography and growth of two tussock grasses in Utah. J. Arid Env. 29: 239-251.

Chambers, J. C.; McMahon, J. H. and Brown, R. W. 1987. Germination characteristics of alpine grasses and Forbs: A comparison of early and late seral dominants with reclamation potential. Reclamation and Reforestation Research 6: 235-249.

Cody, M. L. 1966. A general theory of clutch size. Evolution 20:174-184.

Cook, C. W., Stoddart, L. A. and Kinsinger, F. E. 1958. Responses of crested wheat grass to various clipping treatments. Ecol. Monog. 28: 237-272.

El-Keblawy, A. 2004. Salinity effects on seed germination of the common desert range grass, Panicum turgidum. Seed Sci. Technol. 32: 873-878. 
Flowler, N. L. 1986. Microsite requirements for germination and establishment of three grass species. American Midl. Nat. 115:131145.

Harper, J. L. 1967. A Darwinian approach to plant Ecology. J. Ecol. 55: 247-270.

- 1977. Population Biology of Plants. Academic Press, London.

New York.

Herbel, C. B. 1979. Utilization of Grass- and Shrub-lands of the South-Western United States. In: B. H. Walken (ed.), Management of Semiarid Ecosystems. Developments in Agricultural and ManagedForest Ecology 7: 161-204. Amesterdam-Oxford-New York: Elsevier.

Irvine, F. R. 1952. Supplementary and Emergency Food Plants of West Africa. Econ. Bot. 6: 23-40.

Ismail, A. M. and EI-Seed, M. T. 1983. Some aspects of the autecology of Panicum turgidum Forssk. Qatar Univ. Sci. Bull. 3: 91-101.

Mach, R. R. and Pyke, D. A. 1984. The demography of Bromus tectorum: The role of microclimate, grazing and disease. J. Ecol. 72: 731-748.

Mahmoud, M. I. 1957. Studies on the Plant Growth in the Gravel Desert. M. Sc. Thesis, Science Faculty, Cairo University.

Maire, R. and Monad, T. 1950. Etude sur la Flore et la Vegetation du Tibesti. Paris.

Mazid, A. and Hallagian, M. 1983. Crop-livestock interactions: information from a barley survey in Syria. Farming Systems Program, International Center for Agricultural Research in the Dry Areas, Aleppo, Syria, Research Report No. 10.

Mohammad, N.; Dwyer, D. D. and Bushy, F. E. 1982. Responses of crested wheat grass and Russian wild rye to water stress and defoliation. J. Range Manage. 35: 227-230.

Nachtigal, G. 1988. Sahara et Soudan. Vol. I. Paris.

Oatham, M. P. 1997. Water relations of Zygophillum hamiens, Heliotropium kotschyi and Panicum turgidum and their response to rangeland management techniques in Abu Dhabi. J. Arid Env.35: 95-110.

Peart, M. H. 1979. Experiments on the biological significance of the morphology of seed-dispersal units in grasses. J. Ecol.69: 425-436.

Sankary, M. V. and Barbour, G. A. 1972. Autecology of Haloxylon articulatum in Syria. J. Ecol. 60: 697-711. 
Simpson, N. 1952. Value of the awn in establishing seeds of Danthonia penicillata. (Labill.) Palisot. New Zealand J. Science and Technology 34: 360-365.

Sinha, R. K. 1997. Towards ecological regeneration, biodiversity conservation and environmental restoration of the Thar Desert ecosystem in India. Desert. Controle Bull.30: 28-36.

Tripathi, R. S. and Harper, J. L. 1973. The comparative biology of Agropyron repens (L.) Beauv. and A. caninum (L.) Beauv. I: The growth of mixed population established from tillers and from seeds. $J$. Ecol. 61: 353-368.

Vallentine, .J. F. 1980. Range Development and Improvements. Provo, Utah: Brigham Young University Press.

Weaver, J. E. and Albertson, F. W. 1939. Major changes in grassland as a result of continued drought. Bot. Gaz.100: 576-591.

Weragoda, P. B. 1980. Some questions about the future of traditional medicine in developing countries. J. Ethnopharmacology 2: 193-194.

Williams, J. T. and Farias, R. M. 1972. Utilization and taxonomy of the desert grass Panicum turgidum. Econ. Bot.26: 13-20.

Zahran, M. A. and Willis, A. J. 1992. The Vegetation of Egypt. Chapman \& Hall. London: 424pp

Zohary, M. 1962. Plant Life in Jordan and Israel, the Ronald press, New York: 262pp. 